\title{
"Citizen participation and electricity sector governance in Lithuania: current state and future perspectives"
}

\begin{tabular}{|c|c|}
\hline \multirow{4}{*}{ AUTHORS } & \multirow{2}{*}{ Andrius Stasiukynas (D https://orcid.org/0000-0002-2937-241X } \\
\hline & \\
\hline & Mantas Bileišis (D https://orcid.org/0000-0002-6819-5452 \\
\hline & Vainius Smalskys (D https://orcid.org/0000-0002-2980-792X \\
\hline ARTICLE INFO & $\begin{array}{l}\text { Andrius Stasiukynas, Mantas Bileišis and Vainius Smalskys (2018). Citizen } \\
\text { participation and electricity sector governance in Lithuania: current state and } \\
\text { future perspectives. Problems and Perspectives in Management, 16(3), 189-196. } \\
\text { doi:10.21511/ppm.16(3).2018.15 }\end{array}$ \\
\hline DOI & http://dx.doi.org/10.21511/ppm.16(3).2018.15 \\
\hline RELEASED ON & Wednesday, 08 August 2018 \\
\hline RECEIVED ON & Tuesday, 03 April 2018 \\
\hline \multirow[t]{2}{*}{ ACCEPTED ON } & Thursday, 12 July 2018 \\
\hline & $((c))_{\text {EY-NG }}$ \\
\hline LICENSE & $\begin{array}{l}\text { This work is licensed under a Creative Commons Attribution-NonCommercial } 4.0 \\
\text { International License }\end{array}$ \\
\hline JOURNAL & "Problems and Perspectives in Management" \\
\hline ISSN PRINT & $1727-7051$ \\
\hline ISSN ONLINE & $1810-5467$ \\
\hline PUBLISHER & LLC "Consulting Publishing Company "Business Perspectives" \\
\hline FOUNDER & LLC "Consulting Publishing Company "Business Perspectives" \\
\hline
\end{tabular}

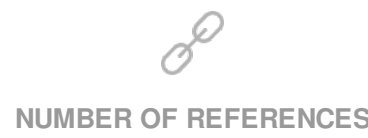

15
NUMBER OF FIGURES

3
NUMBER OF TABLES

0

(C) The author(s) 2023. This publication is an open access article. 


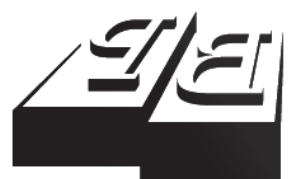

BUSINESS PERSPECTIVES

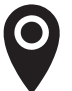

LLC "CPC "Business Perspectives" Hryhorii Skovoroda lane, 10, Sumy, 40022, Ukraine

www.businessperspectives.org

Received on: $3^{\text {rd }}$ of April, 2018 Accepted on: $12^{\text {th }}$ of July, 2018

(c) Andrius Stasiukynas, Mantas Bileišis, Vainius Smalskys, 2018

Andrius Stasiukynas, Ph.D., Professor, Director of the Institute of Public Administration, Mykolas Romeris University, Lithuania.

Mantas Bileišis, Ph.D., Professor, General Jonas Žemaitis Military Academy of Lithuania, Lithuania.

Vainius Smalskys, Ph.D., Dean of the Faculty of Public Governance, Professor of the Institute of Public Administration, Mykolas Romeris University, Lithuania.

\section{(ㄷ)(1) (8)}

This is an Open Access article, distributed under the terms of the Creative Commons Attribution-NonCommercial 4.0 International license, which permits re-use, distribution, and reproduction, provided the materials aren't used for commercial purposes and the original work is properly cited.
Andrius Stasiukynas (Lithuania), Mantas Bileišis (Lithuania),

Vainius Smalskys (Lithuania)

\section{CITIZEN PARTICIPATION AND ELECTRICITY SECTOR GOVERNANCE IN LITHUANIA: CURRENT STATE AND FUTURE PERSPECTIVES}

\begin{abstract}
The paper presents a study, which describes the current governance model of the electricity sector in Lithuania. Electricity and energy production and distribution is highly regulated worldwide. This is also true in Lithuania, where the electricity sector is highly politically prominent, and policy is highly centralized. There are geopolitical concerns towards Russia, which is an important supplier of electricity, and Lithuania's grid is highly integrated with that of Russia. In addition, Lithuania is a small country dominated by a small number of large state-owned producers and has no regional administrations. Lithuania rhetorically has adopted increased citizen participation as a strategic policy goal. The study investigates how far the rhetorics are followed up by policy planning, implementation, and development of new governance modes. The authors base the study on interviews with 19 experts and regulation analysis. The study found that regulation process is transparent, but this causes lower public interest and consequently lower citizen participation". Existing stakeholder involvement at the policy level is highly arbitrary and favorable to large electricity producers. As production is set to decentralize, this has the potential to overburden the regulatory system and cause conflict between different producers.
\end{abstract}

\section{Keywords}

citizen participation, ladder of participation, public governance, governance of electricity sector, renewable energy

JEL Classification H83, E61, Q28, Q48

\section{INTRODUCTION}

Electricity supply directly influences the quality of life for all; it is a fundamental economic activity, which is a prerequisite for nearly all other activities in modern societies. In most countries, therefore, electricity supply is recognized as a "public good" and public authorities act as guarantors of electricity provision. Such guarantees generally have two core elements: (i) uninterruptedness of supply and (ii) price affordability. However, these may not necessarily be achieved through state owned utilities, on the contrary, energy sector governance models are varying from country to country, grid to grid. Choices for particular governance solutions in electricity sectors depend on multiple factors. Yet, one overarching factor since 1980's has been the proliferation of the New Public Management, or NPM, as a default approach to utilities management, which emphasizes market solutions where possible. However, since the 2000's, calls for greater citizens involvement in public or regulated service provision has been a theme that refuses to leave policy agendas worldwide. International organizations have been at the forefront of championing citizen-centered approaches. United Nations "Agenda 21" explicitly states that public authorities must fully cooperate and consult with residents, take into account their needs and traditions, 
including them in the management of natural resources of the country and similar programs (Nefas, 2016). This statement directly affects all energy source extraction, energy production and distribution. European Commission has also been promoting citizen participation in various public governance spheres for many years, and the rhetoric of citizent participation and member states to take it up (Schimanek, 2015).

Involving citizens, communities, NGO's and similarly defined stakeholders in public governance is a much theorized idea, and the need for public managers to integrate these stakeholders in governance is considered commonsensical (Raipa, 2016). An important input into subverting NPM and replacing its notions with citizen-centered approach was that of Ostrom (2015) who found that polycentric governance arrangements are often superior in the efficiency and efficacy of policy outcomes, as opposed to either hierarchical traditional government or market-type NPM solutions.

Lithuania, too, has rhetorically promoted citizen and/or consumer participation in the electricity sector governance and this can be traced to the adoption of EU governance standards leading up to the country's accession in 2004. However, the general zeitgeist of citizen participation at the level rhetorics does not necessarily reflect actual citizen engagement. Depending on a variety of factors, citizen participation varies greatly in different sectors. In the electricity sector, the key prerequisite for greater citizen involvement has been the decision to restructure the electricity sector by separating production and distribution companies, and by encouraging the distribution company, a monopoly, to buy electricity off the market, which in recent years has been internationalized, and non-state owned companies began to produce a large share of electricity. The energy sector in Lithuania also has a powerfull and politically independent regulator - the National Control Commission for Prices, and Energy (NCCPE). In addition, the ever-stricter EU standards for greenhouse gas emissions and pollution have lead to increased small-scale production of reneweables by various producers, including individual households. Nonetheless, the large state-owned producers, and the state-owned monopoly distributor, remain key stakeholders in the electricity sector. Moreover, highly centralized political decision-making and political prominence of energy policy in national politics has on multiple occasions led to questions being raised whether electricity sector is governed in the public's interest.

This aim of this article is to present a study detailing how formal orientation towards citizen participation is actually expressed and how these outcomes relate to the structure of the electricity sector, and to discuss what challenges are likely to occur in the near future as structural changes in the sector accelerate. The article contains four sections: (i) a discussion on theoretical assumption on the benefits of citizen participation and factors encouraging that participation, (ii) an overview of the empirical study design, and analyses of (iii) how the current structure of the electricity sector impacts citizen participation, and (iv) what governance challenges currently developing structural changes will pose in the near future.

\section{LITERATURE REVIEW: HOW ARE BENEFITS OF CITIZEN PARTICIPATION CONSTRUCTED?}

Arnstein (1969) defines citizen participation as a process in which public representatives, who are not officially elected or not appointed to take decisions, are involved, along with the officials, in drawing up the agenda and/or making decisions on topical issues or public policy that affects their interests. Main advantages of citizen participation that are often cited are: i. better policy decisions, because governments can access competencies throughout the society;

ii. better and faster interaction between government and citizens, which leads to greater support for policy and fewer missunderstandings in policy intents;

iii. better identification of needs of citizens;

iv. greater accountability and transparency due to out-of-government actor oversite (Bovaird \& Loffler, 2003). 
More specifically, well-managed citizen participation is likely to involve the most responsible and engaged citizens who would later promote policy throughout the society (Walker \& Daniels, 1997). Non-election constituency-based government-society interactions are not a new phenomenon (Denhardt \& Denhardt, 2003), and multiple mechanisms have been applied almost as long as the modern state has existed, among them: advisory committees, public hearings, surveys, feedback questionnaires, analysis of administrative data, e.g. inquiries and complaints (Rowe \& Frewer, 2005). Nonetheless, greater citizen participation means greater transparency, and errors or shortcomings of capacity may lead to greater loss of trust and legitimacy on the part of governing bodies, and participation mechanisms by which that trust can be regained are far from clear, if e.g. they are contingent on general regulation, which only a parliament could amend. Factors that were found to impact the success of citizen participation include both the governance setup and the social context in which it is placed, such as (i) the level of civic activity and (ii) overall levels of trust in a society, the (iii) culture of informing the public, and (iv) actual conditions (practicalities) of participation (Callahan, 2007). Relevant stakeholder involvement is also crucial. Overlooking key stakeholders and involving groups of that are not directly affected may reduce the effectiveness of governance (Ho, 2007).

Citizen participation poses important challenges to public managers, because it by definition includes stakeholder groups with varying levels of political power, differing interests, and complex mutual interdependencies (Carpini, Cook, \& Jacobs, 2007). Mismanagement risks lead to worse outcomes of pursuing a policy without the element of citizen involvement. Nonetheless, in most cases, when managed properly and all other things being equal, citizen participation is a means to increase governance effectiveness (Bovaird \& Loffler, 2003).

\section{STUDY DESIGN AND METHODOLOGY}

Our analysis is based a semi-structured expert interview analysis of 19 experts. The semi-structured interviews were conducted with persons who are working as high-rank utilities managers (eight persons representing production and distribution companies), energy policy decision-makers (five persons), and independent energy experts (six persons). The criteria for expert selection were: longterm experience in the electricity sector and recommendations on a "snowball" princpile, where initial interviewees would identify other key persons in the sector. Once we began to receive recommendations to interview the same people, we considered the expert pool to have saturated and stopped the inquiry. In some cases, interviews were not possible. Interviewees generally requested anonymity; therefore, we made the decision to anonymize the entire sample.

Before beginning the interviews, we conducted the regulation analysis of the energy sector to identify officially recognized stakeholders. Based on that analysis, we constructed the governance model of the electricity sector. During the interviews, in the first block of questions, we asked the experts to comment our initial findings. Next, we structured our questionnaire on the Arnstein's (1969) "Ladder of citizen participation". We asked the experts to comment on how they viewed the participation of each stakeholder group from the point of view of Arnstein's classification. Also, we asked experts to elaborate on their answers and to differentiate the various government agencies with regard to how effective they are in encouraging, organizing, and utilizing instruments of participation. In the third block, we asked the experts to describe the changes that the electricity sector is undergoing and what challenges may these changes pose for the governance of the sector.

Arnstein's ladder identifies three broad categories of participation: (i) non-participation; (ii) tokenism; and (iii) citizen control. The three categories are further subdivided in case of non-participation into manipulation and therapy. Both of these modes use citizen participation not as a means for policy-making, but as a means of upeasement. Tokenism is subdivided into informing, consulting and placation. Informing does not aim to collect feedback, whereas consulting does. Placation is form of citizen participation where citizens can formulate policy, but the final decision to adopt policy is retained by the official authority. Citizen control is subdivided into partnership, delega- 
tion, and citizen control. These see participating citizens as a necessary element of policy-making, where the highest step of participation ladder is citizen control with most governance processes overseen or managed by citizen-led formats.

The data we collected allowed us to describe the current governance model in the energy sector, identify the levels of citizen participation, evaluate how and where it is needed to try to achieve higher levels of participation.

Findings: Current state of citizen participation in the electricity sector governance

Even a brief look into legislation will confirm an intuition that (i) consumers, (ii) producers, and (iii) public authorities are core stakeholder categories in electricity sector governance. However, the first two categories can be further subdivided. We found the size and organization type to be important factors. Consumers can be both citizens and their associated groups. Businesses, when they are consumers, also vary in size and differ in ownership. The same applies to production companies: the electricity sector is dominated by large powerplants, but the policy of renewable energy technology also serves to democratize the energy production and brings in new types of producers. Indeed, a consumer/producer distinction in many cases becomes difficult to make, because households and businesses begin to create production capacity.

The government has also created a distributed system of agencies, which not necessarily manage to maintain policy cohesion. In Lithuania, procedures for environmental impact assessment and territorial planning require public consultation. Organizers need to hold hearings.

Hearings and surveys are generally seen by developers and regulators as a procedural necessity. The findings from hearings and surveys are not compulsory, and experts noted that they are seldom taken into account. Appeals procedures are also in place and are often used. It seems developers generally believe that risks and costs of appeals are lower than the implementation of hearing results. This may be explained by the fact that often developers tend to augment hearings and surveys with consultations with stakeholders whom they choose on their own accord both before and after hearings. Other explanations may be that the electricity sector and energy sector in general in Lithuania are of high political prominence. The reason for that is Lithuania's historical dependency on energy supplies from Russia, which is a geopolitical adversary for Lithuania. Therefore, the highest government institutions are constantly involved in energy policy formulation (Stasiukynas \& Patapas, 2006). Experts confirmed high political prominence of the electricity sector. The Parliament, Government, and Ministries of Energy and the Environment were the main institutions cited. At the level of executive agencies, NCCPE is the most prominent actor. Other agencies cited included Energy Agency and State Energy Inspection, but experts saw them as minor and specialized actors who had little impact on the overall governance, as they concern themselves more with the technical aspects of the sector, which are highly standardized internationally.

Figure 1 summarizes the findings about the structure and process of the energy sector governance in Lithuania. The political stakeholders: Parliament, Government, and Ministries develop energy policy based on general policy-making procedures. NCCPE is the supervising agency that integrates the various political outputs and attempts to maintain the sustainability of operations in the sector. The electricity sector has producers and distributers of varying size. While the larger organizations receive direct inputs from political institutions, and in most cases are stateowned, the smaller stakeholders need to abide by NCCPE rules.

As mentioned, energy policy is highly centralized due to geopolitical issues and dominant role of a small number of large producers. It must also be noted that Lithuania is a small country and does not have regional administrations. The Parliament adopts key laws that determine not only the governance rules, but also policy in the electricity sector. Parliamentary decisions are taken through the parliamentary Statute, which foresees public hearings at the committees. These are generaly open to the public, and periods for proposals by the public are also awarded. However, expert interviews indicate that in 


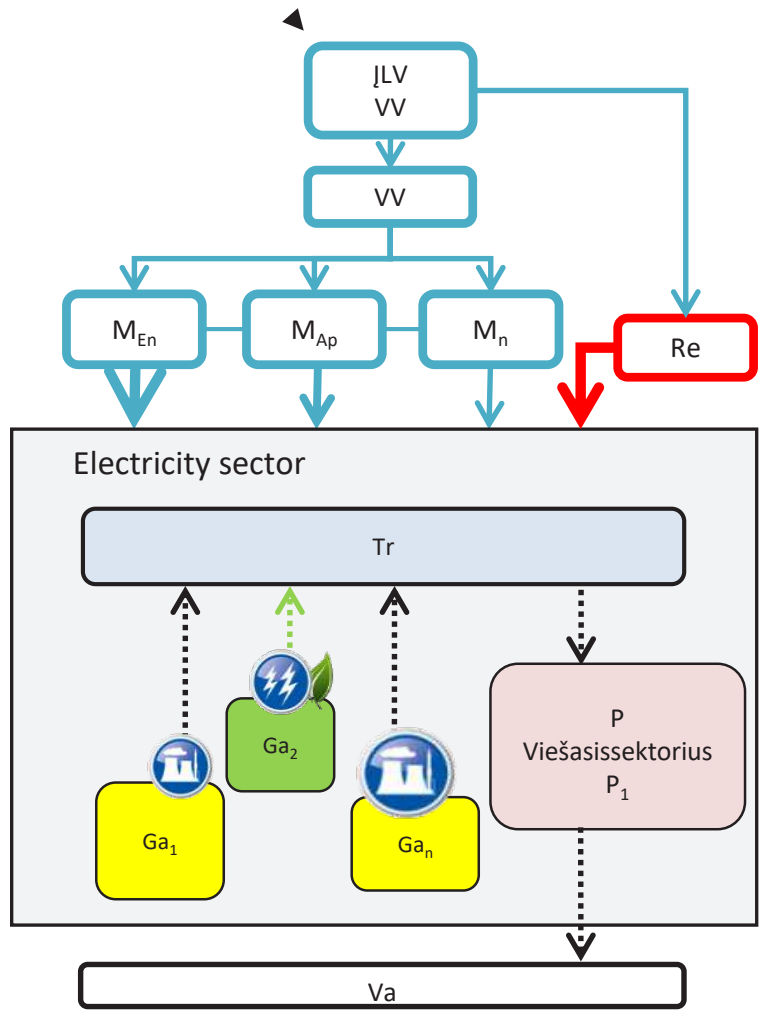

The direction of management subordination, the volume of the index indicates the strength of subordination.

Regulator conducts legal and economic regulation of the sector.

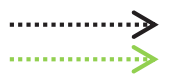

Technical connection between the participants of the sector indicating the targeted flows of electricity:

- energy produced using traditional energy resources;

- energy produced from renewable energy sources.

Notes: $\mathrm{LLV}$ - legislative power; VV - Head of the executive power institution; Re - sector regulator function; $\mathrm{M}_{\mathrm{En}}$ - the Ministry guiding the implementation of energy policy; $M_{A p}$ - the Ministry guiding the implementation of environmental policy; $M_{n}-$ other Ministries; $\mathrm{Tr}$ - electricity transmission/transportation networks and the institution overseeing them; $\mathrm{Ga}$ - commercial electricity producers; P - energy distribution networks; Va - all entities using electricity.

Figure 1. Current model of electricity sector governance in Lithuania

some cases, questionable committee hearing practices have occured where some stakeholders were not allowed to participate by not informing and/or failing to issue permits to the Parliament in due time. Most legislation is drafted at the Government and Ministry levels and later, after the adoption of laws, detailed procedures are passed mostly by orders of the Ministers. Executive institutions have a big leeway when it comes to pricing and citizen participation procedures. There is an instrument to set buying quotas for so-called guaranteed reserve producers, and reneweable sources at prices above market level. These institutions can and do seek consultations with stakeholders. However, in contrast to the Parliament, this process is highly arbitrary and depends on the decisions of particular officials. Experts also stress that electricity policy is seen as irrelevant to the general population due to low prices of electricity, and universal access to it in the country, therefore general population is not considered a stakeholder it his policy area by most institutions and officials.
NCCPE is the agency that implements regulations in the electricity, natural gas, heat and water markets. The NCCPE is required to conduct its business, i.e. take regulatory decisions very transparently: regulatory decisions are made in hearings, the public is informed of drafts of decisions and procedures for complains are well established. NCCPE also is obliged to make sure that their decisions are compatible with any other regulations, therefore NCCPE intensively consults with other government agencies. All government organizations need to make their decisions publicly available, and generally do that through their own or the national registers. However, such registries are complicated to use for non-experts, and the media informs of events in the electricity sector only sporadically. Therefore, the existing participation mechanisms do little to prevent complains or conflicts among stakeholders in their early stages of decision-making. Citizens are in no way involved in the management and oversight of the government bodies of the electricity sector: neither in government agencies nor in state-owned companies. 


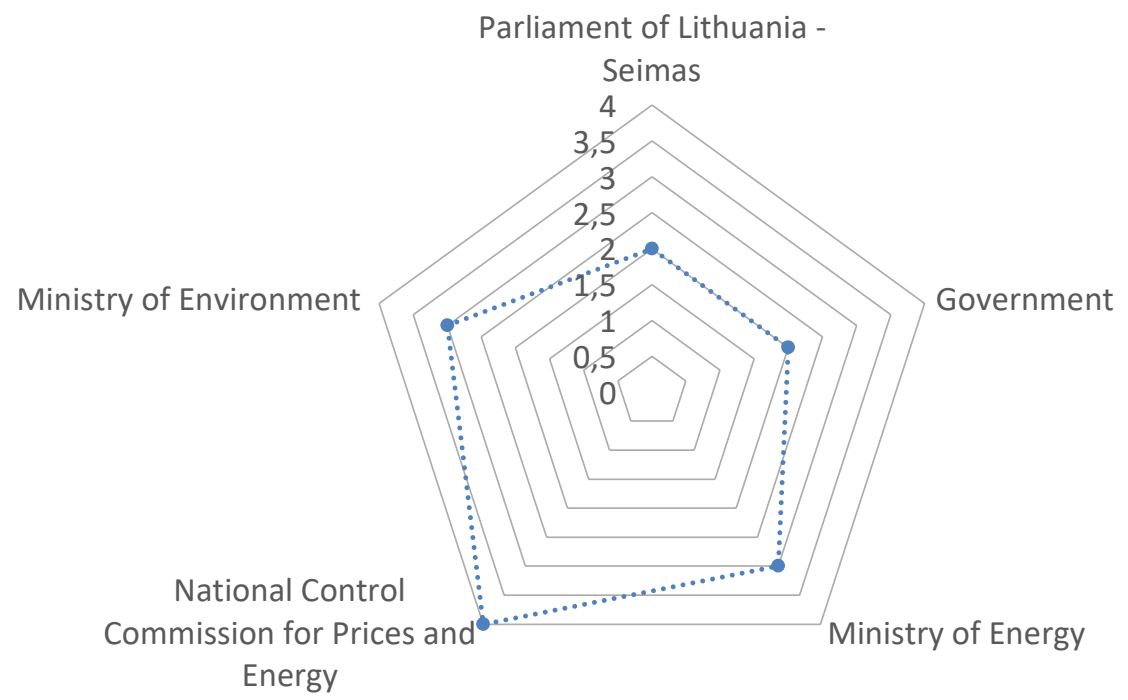

Notes: 1 - Manipulation, 2 - Therapy, 3 - Informing, 4 - Consultation, 5 - Placation, 6 - Partnership, 7 - Delegated power, 8 Citizen control

Figure 2. Citizen participation levels in the electricity sector governance in Lithuania

Therefore, the current governance model of the electrity sector only is some cases meets the standards of tokenism, and the little participation that exists is highly formal. Expert interviews show that bar NCCPE, which reaches the level of consultation with relevant stakeholders, government institutions hover around informing or therapy categories. For example, hearings in the Parliament are slightly more effective than therapy exercises, where citizens can vent their frustrations, and be encouraged to adapt to inevitable changes in return (see Figure 2 for aggregated score from expert interviews).

In addition to low prices and universal availability of electricity, experts cited the need for technical understanding as an important reason for the lack of citizen participation. This is one of the reasons that renewable energy by small producers is developing slower that could do if a larger section of society became engaged in the governance of the electricity sector. Several experts cited education and consultation of citizens as potentially beneficial functions of the sector's government agencies, which is currently next to non-existent. In addition, it needs to be noted that consumer organizations have been in recent years active in the energy sector with regard to centralized heating, this engagement seeps through into the electivity as regulators and producers of the two significantly overlaps.

\section{DISCUSSION}

All experts converged that as reneweable energy production increases, the production continues to decentralize and more and more households will become producers. As they do so, the energy sector will need to adapt to accommodate these new stakeholders, and a smooth adaptation to this structural change is very important for both the economy and the legitimacy of the government, but the current governance model is ill-equiped to face this task.

The growth in complexity of the sector primarily due to the loss of a clear boundary of what constitutes a consumer and producer among small businesses and households in the opinion of the experts is also leading to the fragmentation of distribution networks, therefore the large stateowned company will face challenges on their own. Changes in the structure will take longer and are harded to predict, but their impact may be profound. The growing complexity will put pressure on NCCPE to accommodate the interests of various stakeholder groups. However, without a feedback loop to the level of the Ministries, it is unlikely that NCCPE will able to cope, as it is constrained by regulation, and consultations at the level of NCCPE will not suffice in a more dynamic electricity sector. We see a need for a more formalized citizen pariticipation at the level of ministeri- 


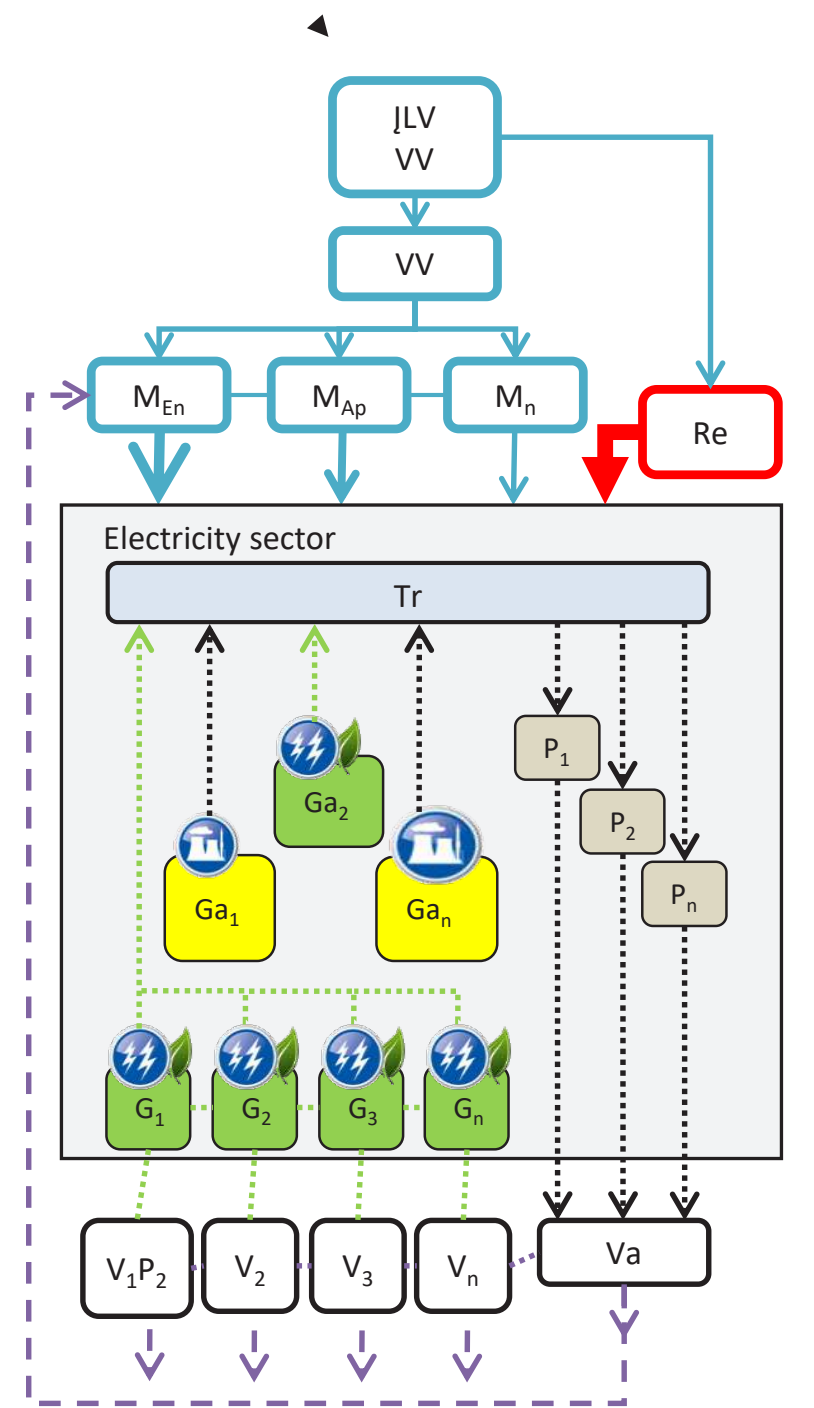

Trend of governance subordination, the arrow marks the level of subordination.

Legal and economic regulation of the sector performed by the regulator.

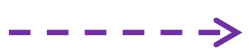

Consumer participation in activities of MEn institutions as interest representatives of the public influencing the governance of the sector performed by the institution.

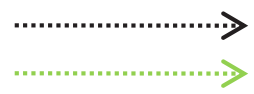

Technical relationship among the participants of the sector marking the directional flows of electricity:

- electricity flows produced from traditional energy sources;

- electricity flows produced from renewable energy sources.

Notes: ILV - legislative power; VV - lead institution of executive power; Re - institution performing the regulatory role of the sector; $\mathrm{M}_{\mathrm{En}}$ - the Ministry monitoring energy policy implementation; $\mathrm{M}_{\mathrm{Ap}}$ - the Ministry monitoring environmental policy implementation; $\mathrm{M}_{\mathrm{n}}$ - other Ministries; $\mathrm{Tr}$ - electricity transmission networks and the supervising institution; $\mathrm{Ga}$ - commercial electricity producers; $\mathrm{G}$ - small producers producing electricity to partially meet their own needs; $\mathrm{P}$ - energy distribution networks; V - energy consumers (including households and communities) producing energy to meet their own needs; Va - other consumers of electricity.

Figure 3. A model for increased citizen participation in the governance of electricity sector in Lithuania

al decision-making in anticipation to the inevitable technological and business process changes in the sector (see Figure 3).

Academic literature shows that there is a great variety of instruments for citizen participation, and their success may depend on slightest nuances of the context in which they are used. Currently, at the ministerial level, few if any of those methods were tested or piloted, to say nothing of their systematic adoption into policy-making practice. Equally, no attempts at educating in inter- est representation of incoming small producers are made, which create conditions for conflictual, rather than co-operative energy sector governance processes in the future (Bileišis, Guogis, \& Šlinskytė, 2014). Although we recognize that allocating resouces required to develop well-functioning participatory systems is complicated (Franklin \& Ebdon, 2007), there is a clear case to investigate the feasibility of investing into such changes both from the point of view of their impact on reducing risks to the sector and creating new value. 


\section{CONCLUSION}

The Lithuanian electricity sector has low levels of citizen participation. Stakeholder involvement at the policy level is highly arbitrary and favorable to large electricity producers. The regulation process is transparent, but is highly regulated; therefore, citizen participation could only achieve limited resuls. There are two key weaknesses to the current governance model - it is ill adapted to a more decentralized production structure of the electricity sector, and probably even more so to the decentralization of the distribution. Lithuania does encourage the small-scale production from renewable sources, on the one hand, but does not invest in education or accommodation interests of the new producers. As this type of stakeholder becomes more prolific, the energy sector may face tensions of interests, which could impede the development of the sector and negatively affect the legitimacy of the government. Clearly, at least mechanism that are more highly complex forms of tokenism, such as consulting, and placation should be considered for official adoption by Ministries of Energy and the Environment in the process of electricity policy formulation.

\section{REFERENCES}

1. Arnstein, S. R. (1969). A ladder of citizen participation. Journal of the American Institute of planners, 35(4), 216-224. https://doi. org/10.1080/01944366908977225

2. Bileišis, M., Guogis, A., \& Šilinskytè, A. (2014). Government-community conflict: the Lithuanian public governance challenge. Public Policy and Administration, 13(1), 22-35. https://doi.org/10.5755/j01. ppaa.13.1.6404

3. Bovaird, T., \& Loffler, E. (2003). Public Management and Governance. Routledge.

4. Callahan, K. (2007). Elements of effective governance: measurement, accountability and participation. New York: Taylor \& Francis.

5. Carpini, M. X. D., Cook, F. L., \& Jacobs, L. R. (2007). Public Deliberations, Discursive Participation and Citizen Engagement: A Review of the Empirical Literature. Annual Review of Political Science, 7(1), 315-344. Retrieved from https://www.scholars.northwestern.edu/en/publications/public- deliberation-discursive-participa-

tion-and-citizen-engageme

6. Denhardt, J. V., \& Denhardt, R. B. (2003). The New Public Service: Serving, not Steering. M. E. Sharpe: NY.

7. Franklin, A. L., \& Ebdon, C. (2007). Democracy, Public participation and Budgeting. Mutually Exclusive or Just Exhausting? In R. C. Box (Ed.), Democracy and Public Administration. Routledge.

8. Ho, A. T. (2007). Citizen Participation in Performance Measurement. In R. C. Box (Ed.), Democracy and Public Administration. Routledge.

9. Nefas, S. (2016). Modernios vietos (teritorijos) savivaldos ir valdymo demokratizavimo bruožai [Features of modern local community governance democratizations]. In A. Raipa (Ed.), Šiuolaikinio viešojo administravimo pagrindai. Vilnius: Registrų centro leidykla.

10. Ostrom, E. (2015). Governing the commons. Cambridge university press.

11. Raipa, A. (2016). Viešosios vertès kūrimas naujojo viešojo valdymo struktūrose. Viešoji politika ir administravimas, 15(2), 220-234.

12. Rowe, G., \& Frewer, L. J. A. (2005). A typology of public engagement mechanisms. Science, Technology \& Human, 30(2), 251-290. http://dx.doi. org/10.1177/0162243904271724

13. Schimanek, T. (2015). Partycypacja obywatełska w społeczności lokalnej (FISE) [Participation of citizens in local governance]. Warszawa: Druk: Chromapress.

14. Stasiukynas, A., \& Patapas, A. (2006). Lietuvos elektros energetikos administravimas ir jo raidos ypatumai [Administration of the Lithuanian Energy Sector: Features and Development]. Viešoji politika ir administravimas, 17 , 49-60.

15. Walker, G. B., \& Daniels, S. E. (1997). Collaborative public participation in environmental conflict management: An introduction to five approaches. In S L. Senecah (Ed.), Proceedings of the Fourth Biennial Conference on Communication and Environment. Syracuse. NY: State. 